\title{
The Effects of Obstructive Factors and Rewards Related to Technological Innovation on Management Performance: Focusing on Chinese Companies
}

\author{
Eun-Mi Park $^{1} \&$ Joung-Hae Seo ${ }^{1}$ \\ ${ }^{1}$ Department of Business Administration, Kyungpook National University, Daegu, South Korea \\ Correspondence: Joung-Hae Seo, Department of Business Administration, Kyungpook National University, 80 \\ Daehakro, Bukgu, Daegu, 41566, South Korea. Tel: 82-53-950-5419. E-mail: knight6407@ naver.com
}

Received: April 9, 2020

Accepted: May 9, 2020

Online Published: May 23, 2020

doi:10.5430/rwe.v11n2p98

URL: https://doi.org/10.5430/rwe.v11n2p98

\begin{abstract}
Background/Objectives: This study empirically analyzed the factors relevant to the effects of Obstructive factor and rewards on Technical performance and Image, management performance.

Methods/Statistical analysis: In this study, PLS, a analytic method, was used among other structural equation models. PLS is not structurally strict and helpful in analyzing models at the early phase of developing theories despite incomplete models. This study conducted online survey among Chinese companies.

Findings: Rewards gave positive effects on technological performance and images. Furthermore, technological performance showed the same effects on images and performance. Images gave the same effects on business performance.
\end{abstract}

Improvements/Applications: This study demonstrated the important relationship between obstructive factors and rewards, technical performance and image, which will serve as a guideline for further management performance.

Keywords: obstructive factors, rewards, technical performance, image, management performance

\section{Introduction}

The first industrial revolution had brought many changes to human life. Following the second and third industrial revolutions, a new trend based on the Information and Communication and Technology (ICT) has taken on the global stage: the Fourth Industrial Revolution. This cutting-edge movement employs Artificial Intelligence (AI): big data, Internet of Things (IoT): Cloud, 5G mobile, blockchain technology, Virtual Reality and Augmented Reality (VR $\cdot A R$ ) and hyper-detection sensor technology. Such essential technologies are applied in and connected with pre-existing industries covering robot, automobile, factory and medical service (Li et al., 2019; Park et al., 2019; Park et al., 2018).

Such new trend demonstrates the importance of technological innovation. In the viewpoint of customers, it makes life abundant and meaningful. Businesses recognize that such technological innovation is a source of advantage that promotes the creation of new markets. Thus, it is a significant element directly tied to the survival of companies.

Companies make various attempts to survive the fierce competition by developing new source technologies and releasing new products and services. Innovation drives such changes. In doing so, companies are exerting more efforts to survive such competitive conditions. In a bid to successfully and effectively bring success to such innovation, many people make joint efforts. They should reinforce positive aspects and remove negative ones to reach successful levels.

Obstructive factor refer to diverse activities that interrupt innovations led by companies. Rewards boost their strengthened efforts toward innovation. Rewards, regarded as a positive element, are classified into monetary reward and non-monetary reward (Park et al., 2013). The monetary reward can serve as an obstructive factor to pushing ahead with innovation, while non-monetary reward boost innovation yet considers the possibility of drawing poor results.

Under the current circumstances where globalization is being accelerated, there is no borderlines and geographical merits. As technology advances, companies are pushed by more competitive situations. To survive it, they will exert more efforts in investing funds in technological innovation.

Despite such efforts, many earlier studies mainly focused on factors affecting technological innovation. There is little 
research on the effects of obstructive factor and rewards related to technological innovation on management rewards. This study will examine the effects of obstructive factor and rewards on technological performance, images and business performance.

\section{Theoretical Background}

\subsection{Technological Innovation}

Schumpeter (1934) mentioned "creative destruction" as technological innovation (Schumpeter, 1934). Based on his research, Schmookler (1966) categorized technological innovation into product innovation and fair innovation (Schmookler, 1966). Freeman (1982) defined it as commercial transaction on new products and components from fair system (Freeman, 2013). Damanpour \& Evan (1984) said that it brings change to organizations through the application of new products, services, systems, process, programs and instruments into organizations (Damanpour and Evan, 1984).

Rogers (1995) defined it as technological process through which new products are made, products are changed and process is evolved. In other words, technological innovation can be said to completely shift existing methods or organizations in terms of technology (Rogers, 2002).

\subsection{Obstructive Factor}

Stefflre (1985) analyzed obstructive factor in technological innovation implemented by organizations (Stefflre, 1985). Later on, Veugelers \& Cassiman (1999) suggested that diverse obstructive factor arising from technological innovation interrup such activities and that these obstructive factor play a decisive role in selecting and utilizing strategies for acquiring essential skills (Veugelers and Cassiman, 1999).

Mohnen \& Rosa (1999) argued that there are a wide range of obstructive factor such as feasibility in implementing corporate innovation, market risk, excessive costs, financing, resource availability for carrying out innovation, internal resistance and regulatory environment (Mohnen and Rosa, 1999). Baldwin \& Lin (2002) analyzed the effects of obstructive factor associated with expense, institution, personnel, organization and information on the adoption and use of new technologies (Baldwin and Lin, 2002). They noted that companies confront various obstructive factors in the process of innovation. They added that the more innovative they become, the more they face obstructive factor.

Galia \& Legros (2004) noted the difference of obstructive factor between postponed projects and abandoned projects (Galia and Legros, 2004). They argued that the obstructive factors are correlated to seek tangible policy packages aimed at encouraging companies to take part in such innovation. Mohnen \& Roller (2005) confirmed that the complementary and alternative associations of obstructive factor vary according to preference and degree of innovation, and that the level of obstructive factor differs depending on corporate and industrial characteristics (Mohnen and Röller, 2005).

Park et al. (2013) analyzed the influential factors between patent activities and management. They argued that rewards affect cooperation, and cooperation significantly affect obstructive factor (Park et al., 2013). In addition, the obstructive factor s gave a significant impact on technological images, and these images affected corporate images and performance.

\subsection{Reward}

A theory of learning notes that reward is a statically reinforcing element that causes positive behaviors. Such rewards include materials such as monetary benefits, food and clothes, or non-materials such as praise, acknowledgement and expressing gratitude. Rewards from certain behaviors serve as reinforcing agents, thereby increasing the possibility of reiterating the same acts under similar circumstances.

Jaworski and Kohli (1993) suggested that rewards are important instruments to form waiters' behaviors (Jaworski and Kohli, 1993). Park et al. (2013) said that in case companies give proper rewards to employees, patent-related activities will be revitalized, boosting cooperation and sharing information with the employees (Park et al., 2013). Thus, fair and appropriate rewards boost technological innovation, positively affecting technology and business performance (Uzochukwu and Uchenna, 2019); (Wen and Liao, 2019).

\subsection{Technological Performance}

Outcomes from implementing innovative measures generally lead to tangible and various results such as technological performance, economic rewards, product rewards and business performance (Park et al., 2013). The examples include the development of new technologies, release of new products and services and shortening the period of developing new technologies through technological innovation. 


\subsection{Image}

Images are sensory phenomena resonated by senses. Companies regard it as special loyalty such as brand, company and technology distinct from other competitors (Park et al., 2013). Many businesses are making various efforts to enhance such brands. For instance, they highlight technological advantages such as developing and releasing first-ever new products to consumers, thereby garnering their loyalty to companies and their brands.

\subsection{Management Performance}

Neely et al. (1995) said that measuring business performance is a process of assessing the efficiency and effectiveness of business management (Neely et al., 1995). They added that rewards measuring index is a combination of instruments for assessing the efficiency and effectiveness. They attend to fulfill financial performance with only past invalid information regardless of a traditional performance: improvement of future performance.

Some scholars suggested considering both financial statements and non-financial measurements, underscoring the need to see the viewpoints of company, innovation, learning and customers in addition to financial aspects (Kaplan and Norton, 2001). Acha (2000) classified technological innovation abilities into research and development expenses and patent, and proposed the relevance with business performance (Acha, 2000).

\section{Research Model and Hypothesis}

In this study, obstructive factor and rewards were set as independent variables. The correlations were statistically analyzed by setting technological performance and images as mediating variables, and management performance as dependent variables. The research model was shown in the Figure 1. Hypotheses are shown as follows.

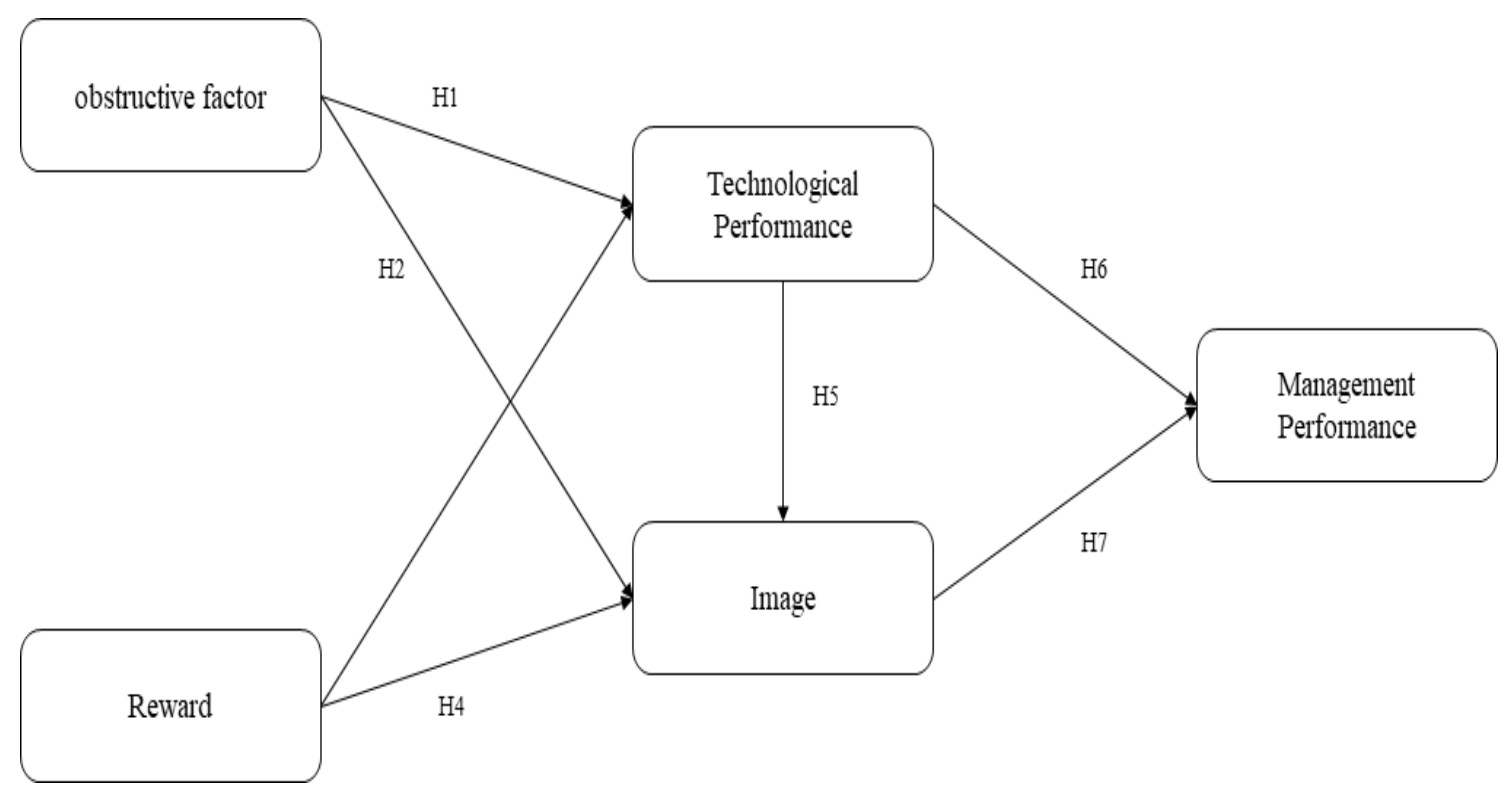

Figure 1. Research models

Companies make huge investments in technological innovation. Many of them undergo difficulties in the process due to multiple obstructive factor. Identifying and addressing such challenges would give a positive impact on their images and rewards. The following two hypotheses are shown.

\section{H1. Obstructive factor in technological innovation will positively affect rewards.}

\section{H2. Obstructive factor in technological innovation will positively affect images}

Companies with an appropriate and fair reward system encourage employees, laying a groundwork for growth. Samsung distributes annual surplus to employees in the early days. Employees are encouraged to facilitate innovation through monetary rewards. To be sure, companies capable of balancing non-monetary rewards and monetary ones will give positive effects on technological performance. In this sense, two hypotheses were shown as follows.

H3. Rewards coming from technological innovation will give a positive impact on technological performance. 
H4. Rewards coming from technological innovation will give a positive impact on images.

Technological performance positively affects improving corporate images. These rewards encompass generating patent, practical methods, management secrets and copyrights out of the outcomes of research and development. Such technological performance and contributions demonstrate the leadership role played by businesses, ultimately giving positive effects on management performance. Technological performance through innovation would positively influence corporate images and performance. In this sense, two hypotheses were shown as follows.

\section{H5. Technological performance will positively affect images.}

H6. Technological performance will positively affect management performance.

Corporate images are regarded as identical with brand images. Thus, enterprises seek ways to enhance performance as well as images. Images such as brand, company and technology give a positive impact on their management performance. In this regard, a hypothesis was shown as follows.

\section{H7. Images will positively affect management performance.}

\section{Results}

\subsection{Sample and Method}

In this study, PLS, an analytic method, was used among other structural equation models. PLS is not structrually strict and helpful in analyzing models at the early phase of developing theories despite incomplete models. Furthermore, this statistic technique can be used to give optimally practical assessments to theoretically structural models and assessment models (Park et al., 2013; Chin).

This study conducted online survey among Chinese companies. In total, 172 participants responded at the survey held from September 1 to September 20, 2019. Except for four invalid responses, 168 papers were used in actual analysis. For genders, men accounted for 54.3\% (108) and women accounted for $25.7 \%$ (60). As to academic background, high school accounted for 3.57\% (6): college accounted for $76.79 \%$ (129): and graduate school accounted for $19.64 \%$ (33). In average, they worked for six years.

\subsection{PLS Analysis}

PLS requires standards such as internal consistency, convergent validity and discriminant Validity as part of validation. Internal consistency is validated using composite reliability and reliability. Internal consistency is deemed appropriate if composite reliability is over 0.8 and Cronbach's alpha ranges from 0.6 to 0.7 . However, it is not a fixed index, yet vary according to participants and situations. Nunnally (1967) mentioned that over 0.5 is reliable (Nunnally, 1987). In this study, internal consistency was appropriate as all other variables, except for reward (0.5847): met standards. Discriminant Validity Analysis was shown in the Table 1.

Table 1. Discriminant validity analysis

\begin{tabular}{|c|c|c|c|c|}
\hline & $\begin{array}{c}\text { Factor } \\
\text { Loading }\end{array}$ & Composite Reliability & AVE & $\begin{array}{c}\text { Cronbachs } \\
\text { Alpha }\end{array}$ \\
\hline IP1 & 0.7624 & \multirow{4}{*}{0.835} & \multirow{4}{*}{0.5587} & \multirow{4}{*}{0.737} \\
\hline IP2 & 0.7676 & & & \\
\hline IP3 & 0.7346 & & & \\
\hline IP4 & 0.7244 & & & \\
\hline OF1 & 0.8873 & \multirow[t]{4}{*}{0.8843} & \multirow{4}{*}{0.6596} & \multirow[t]{4}{*}{0.849} \\
\hline OF2 & 0.7458 & & & \\
\hline OF3 & 0.9114 & & & \\
\hline OF4 & 0.6814 & & & \\
\hline MP1 & 0.7977 & \multirow[t]{3}{*}{0.7983} & \multirow[t]{3}{*}{0.5699} & \multirow[t]{3}{*}{0.6243} \\
\hline MP2 & 0.7774 & & & \\
\hline MP3 & 0.6849 & & & \\
\hline
\end{tabular}




\begin{tabular}{|c|c|c|c|c|}
\hline RE1 & 0.7631 & \multirow[t]{3}{*}{0.7814} & \multirow[t]{3}{*}{0.5439} & \multirow[t]{3}{*}{0.5847} \\
\hline RE2 & 0.7187 & & & \\
\hline RE3 & 0.73 & & & \\
\hline TP1 & 0.7674 & \multirow[t]{3}{*}{0.8052} & \multirow[t]{3}{*}{0.5797} & \multirow[t]{3}{*}{0.6397} \\
\hline TP2 & 0.7843 & & & \\
\hline TP3 & 0.7315 & & & \\
\hline
\end{tabular}

AVE turned out over 0.5 , and factor loading value was more than 0.6. Therefore, convergent validity is reliable (Fornell and Larcker, 1981; Thompson et al., 1995).

Table 2. Correlation between latent variable

\begin{tabular}{cccccc}
\hline & IP & MP & OF & RE & TP \\
\hline IP & 0.7475 & & & & \\
\hline MP & 0.5308 & 0.7549 & & & \\
\hline OF & -0.1241 & -0.0593 & 0.8122 & & \\
\hline RE & 0.5612 & 0.4427 & -0.1498 & 0.7375 & 0.7614 \\
\hline TP & 0.5754 & 0.5949 & -0.0446 & 0.4864 & \\
\hline
\end{tabular}

Discriminant validity can be supported if AVE's square root marked on the diagonal axis must be bigger than the correlation coefficient below. The study revealed that discriminant validity is supported as the smallest value (0.7375) is bigger than the biggest value (0.5754) among other square roots (shown in the Table 2).

Table 3. Hypotheses testing

\begin{tabular}{ccccc}
\hline & Path & Coefficient & T-value & Result \\
\hline H1 & OF -> TP & 0.0289 & 0.4913 & Rejected \\
\hline H2 & OF -> IP & -0.0525 & 1.3951 & Rejected \\
\hline H3 & RE -> TP & 0.4907 & $12.0378^{* * *}$ & Accepted \\
\hline H4 & RE -> IP & 0.3597 & $5.4572^{* * *}$ & Accepted \\
\hline H5 & TP > IP & 0.398 & $6.0663^{* * *}$ & Accepted \\
\hline H6 & TP > MP & 0.4328 & $7.7863^{* * *}$ & Accepted \\
\hline H7 & IP > MP & 0.2818 & $4.4969^{* * *}$ & Accepted \\
\hline
\end{tabular}

It is effective for this structural equation model since it met all the three requirements. Table 3 and Figure 2 show the PLS results of this model. PLS R ${ }^{2}$ showed that obstructive factor and rewards have explanatory power over $23.7 \%$ of technological performance and $43.7 \%$ of images. Both have explanatory power over $40.7 \%$ of management performance. These results are 10\% higher than test power proposed by Falk and Miller (1992) (Chin and Todd, 1995; Falk and Miller, 1992). 


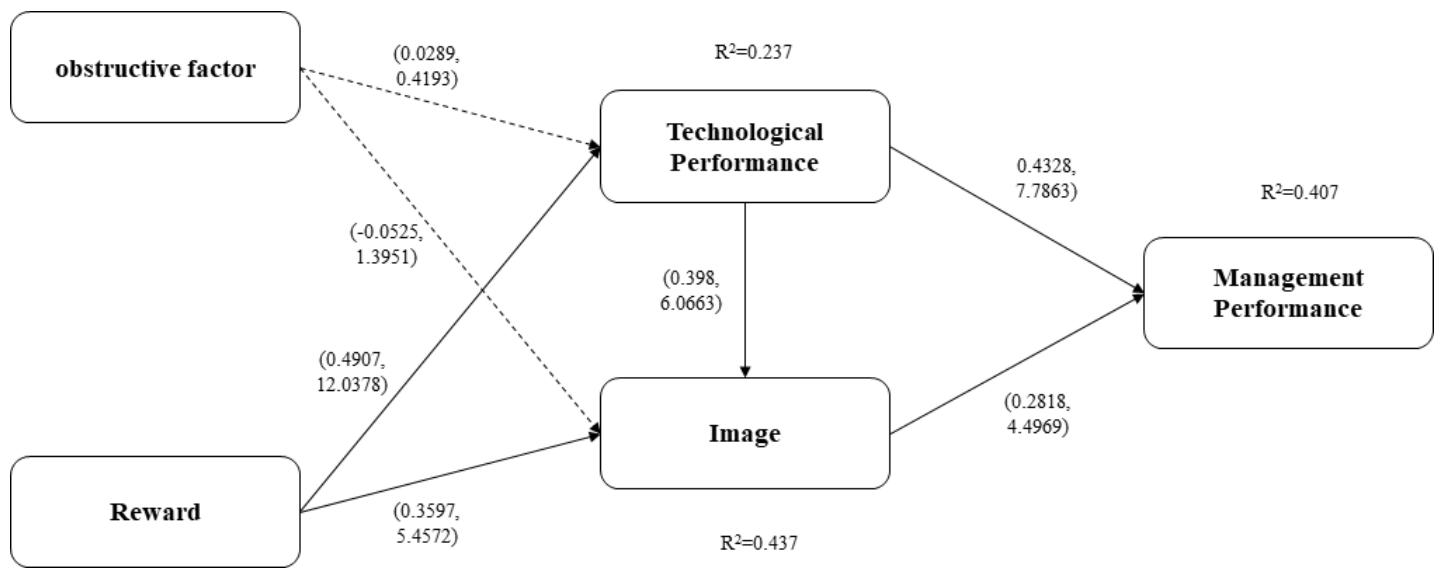

Figure 2. Hypotheses testing

The mediating effects are shown below.

First, the mediating effects of obstructive factor were null, which is consistent with the results of research hypotheses. Technological performance showed mediating effects of management performance. In addition, the same effects were found between image rewards and management performance. Sobel test showed that $\mathrm{t}$ statistics were $\mathrm{t}=6.5348(\mathrm{p}<0.05)$ and $\mathrm{t}=4.4690(\mathrm{p}<0.05)$ : respectively.

\section{Conclusion}

As time progresses, technology advances in the course of innovation. In this era, we live in a rapidly changing society. In particular, business makes continued efforts to survive the Fourth Industrial Revolution era. Balancing obstructive factor and rewards would be more important than any other issue in a bid to achieve technological innovation successfully. Results are shown as follows.

Rewards gave positive effects on technological performance and images. Furthermore, technological performance showed the same effects on images and performance. Images gave the same effects on management performance (Windarti, 2019); (Woon et al., 2019).

It is vital for companies to accomplish technological performance by giving appropriate rewards to employees. In addition to technological performance, fair and appropriate rewards can enhance corporate images, ultimately positively influencing management performance. Nevertheless, the obstructive factor did not affect technological performance and images. Such results are assumed to be derived from Chinese corporate culture. Autonomy and equality in task are guaranteed by Chinese businesses. In addition, there are advantages such as rapid decision-making, various rewards and fast implementation. On this note, obstructive factor may not impede generating better performance. The implications are presented below.

First, many earlier studies focused on the effects of technological innovation and following performance. However, this study identified the association between obstructive factor and rewards, and between technological performance and images resulting from technological innovation among Chinese companies. Second, the findings are expected to be used as a guideline for Chinese corporate executives to carry out technological innovation.

In spite of these implications, the limitations should be mentioned. First, it failed to consider diverse variables influencing technological innovation and management performance. Second, it did not draw variables in terms of industrial characteristics. In the follow-up study, the number of survey participants should be increased. Various variables affecting technological innovation should be gathered and comparing other countries, in addition to China, needs to be implemented.

\section{References}

Acha, V. (2000). The role of technological capabilities in determining performance: The case of the upstream petroleum industry. In The DRUID Conference of Industrial Dynamics, Hillerpd.

Baldwin, J., \& Lin, Z. (2002). Impediments to advanced technology adoption for Canadian manufacturers. Research Policy, 31(1), 1-8.

Chin, W. W., \& Todd, P. A. (1995). On the use, usefulness, and ease of use of structural equation modeling in MIS research: a note of caution. MIS Quarterly, 1, 237-46.

Chin, W. W. (1998). Commentary: Issues and opinion on structural equation modeling. MIS Q., 22, 7-16. 
Damanpour, F., \& Evan, W. M. (1984). Organizational innovation and performance: The problem of "organizational lag". Administrative Science Quarterly, 392-409.

Falk, R. F., \& Miller, N. B. (1992). A primer for soft modeling. University of Akron Press.

Fornell, C., \& Larcker, D. F. (1981). Evaluating structural equation models with unobservable variables and measurement error. Journal of Marketing Research, 18(1), 39-50.

Freeman, C. (2013). Economics of industrial innovation. Routledge.

Galia, F., \& Legros, D. (2004). Complementarities between obstacles to innovation: Evidence from France. Research Policy, 33(8), 1185-99.

Jaworski, B. J., \& Kohli, A. K. (1993). Market orientation: Antecedents and consequences. Journal of Marketing, 57(3), 53-70.

Kaplan, R. S., \& Norton, D. P. (2001). Transforming the balanced scorecard from performance measurement to strategic management: Part I. Accounting Horizons, 15(1), 87-104.

Li, G., Park, E. M., \& Jin, S. J. (2019). The impacts of personal traits on knowledge discovery behaviors via mobile SNS. Personal and Ubiquitous Computing, 1-2.

Mohnen, P., \& Röller, L. H. (2005). Complementarities in innovation policy. European Economic Review, 49(6), 1431-50.

Mohnen, P., \& Rosa, J. (1999). Barriers to innovation in service industries in Canada, Science and Technology Redesign Project. Research Paper, 7.

Neely, A., Gregory, M., \& Platts, K. (1995). Performance measurement system design: A literature review and research agenda. International Journal of Operations \& Production Management, 15(4), 80-116.

Nunnally, J. C. (1987). Psychometric theory. McGraw-Hill.

Park, S. T., Jung, J. R., \& Liu, C. (2019). A study on policy measure for knowledge-based management in ICT companies: focused on appropriability mechanisms. Information Technology and Management, 1-3.

Park, S. T., Li, G., \& Hong, J. C. (2018). A study on smart factory-based ambient intelligence context-aware intrusion detection system using machine learning. Journal of Ambient Intelligence and Humanized Computing, 1-8.

Park, S., Kim, Y. K., \& Kim, T. U. (2013). A study on influencing factors of patent activities on management performance. Entrue Journal of Information Technology, 12(3), 121-9.

Rogers, E. M. (2002). Diffusion of preventive innovations. Addictive Behaviors, 27(6), 989-93.

Schmookler, J. (1966). Invention and economic growth. Harvard University Press.

Schumpeter, J. A. (1934). The theory of economic development: An inquiry into profits, capital, credit, interest and the business cycle. Harvard Economic Studies, 46.

Stefflre, V. (1985). Organizational obstacles to innovation: A formulation of the problem. Journal of Product Innovation Management: An International Publication of the Product Development \& Management Association, 2(1), 3-11.

Thompson, R., Barclay, D. W., \& Higgins, C. A. (1995). The partial least squares approach to causal modeling: Personal computer adoption and use as an illustration. Technology Studies: Special Issue on Research Methodology, 2(2), 284-324.

Uzochukwu, O. C., \& Uchenna, O. N. (2019). Organizational memory and employee performance in federal Parastatals in Enugu State of Nigeria. International Journal of Public Policy and Administration Research, 6(2), 91-101.

Veugelers, R., \& Cassiman, B. (1999). Make and buy in innovation strategies: Evidence from Belgian manufacturing firms. Research Policy, 28(1), 63-80.

Wen, Y., \& Liao, M. (2019). The impact of industrial agglomeration on carbon emissions: Empirical evidence from China. International Journal of Management and Sustainability, 8(2), 67-78.

Windarti, Y. (2019). Residents perception of impacts toward tourism development: The case of Bandung City, Indonesia. Journal of Tourism Management Research, 6(1), 29-44.

Woon, C. K., Singh, J. S. K., \& Singh, J. S. K. (2019). Intention to use e-recruitment system: empirical evidence from jobseekers in the advertising industry in Malaysia. International Journal of Business, Economics and Management, 6(2), 76-86. 